\title{
Gambaran makroskopik dan mikroskopik ureter pada hewan coba postmortem
}

\author{
${ }^{1}$ Dinda N. S. Savalina \\ ${ }^{2}$ Shane H. R. Ticoalu \\ ${ }^{2}$ Sunny Wangko
}

\author{
${ }^{1}$ Kandidat Skripsi Fakultas Kedokteran Universitas Sam Ratulangi Manado \\ ${ }^{2}$ Bagian Anatomi Histologi Fakultas Kedokteran Universitas Sam Ratulangi Manado \\ Email: dindanadyasavalina@yahoo.com
}

\begin{abstract}
Postmortem changes provide a lot of valuable information about the time, causes, and mechanisms of death. This study was aimed to obtain an overview of the macroscopic and microscopic postmortem changes of ureter at several time intervals during 48 hours postmortem. This was a descriptive study using pigs as samples. The results showed that macroscopic postmortem changes of ureters began to appear at 5 hours postmortem marked by changes in color, consistency, and length of the ureters. Meanwhile, the microscopic postmortem changes of the ureters began to appear at 4 hours postmortem characterized by congestion, however, the transitional epithelial cell could be identified. At 5 hours postmortem, a number of transitional cells showed pycnotic nuclei. At 15 hous postmortem, the transitional layer began to detach from the lamina propria; cells with pycnotic nuclei increased in number. At 30 hours postmortem, the transitional layer was detached from the lamina propria and in general the structure of ureter layers could not be identified. Conclusion: Macroscopic changes in color, consistency and length of ureter could be observed the earliest at 5 hours postmortem Microscopic changes could be identified at 4 hours postmortem characterized by congestion, however, the transitional cells could be idemtified. At 5 hours postmortem, the early necrosis of transitional cells occured. At 30 hours postmortem the structure of ureter layers could not be identified.
\end{abstract}

Keywords: macroscopic and microscopic description, ureter, postmortem.

\begin{abstract}
Abstrak: Perubahan postmortem banyak memberikan informasi baik mengenai waktu, penyebab, maupun mekanisme kematian. Penelitian ini bertujuan untuk mendapatkan gambaran makroskopik dan mikroskopik ureter postmortem berdasarkan variasi waktu sampai 48 jam postmortem. Jenis penelitian ialah deskriptif dengan menggunakan babi sebagai hewan coba. Hasil penelitian menunjukkan perubahan makroskopik ureter hewan coba, mulai tampak pada 5 jam postmortem ditandai dengan perubahan warna, konsistensi dan panjang ureter sampai 30 jam postmortem. Perubahan mikroskopik ureter hewan coba postmortem mulai tampak pada 4 jam postmortem ditandai dengan adanya kongesti, sel epitel transisional masih dapat diidentifikasi. Pada 5 jam postmortem sebagian inti sel transisional tampak piknotik. Pada 15 jam postmortem sebagian lapisan epitel transisional telah terlepas dari lamina propia dan sel-sel dengan inti piknotik makin jelas. Pada 30 jam postmortem lapisan epitel transisional dengan inti sel piknotik telah terlepas dari lamina propria dan secara keseluruhan struktur lapisan ureter telah sulit diidentifikasi. Simpulan: Perubahan makroskopik mulai terlihat pada 5 jam postmortem ditandai dengan perubahan warna, konsistensi, dan panjang ureter. Perubahan mikroskopik dapat diidentifikasi pada 4 jam postmortem ditandai adanya kongesti, pada 5 jam postmortem dimulainya nekrosis sel epitel transisional, dan pada 30 jam struktur lapisan ureter telah sulit diidentifikasi.
\end{abstract}

Kata kunci: gambaran makroskopik dan mikroskopik, ureter, postmortem 
Mati adalah berhentinya semua fungsi vital tubuh secara permanen. Untuk kepentingan hukum dan kedokteran, digunakan definisi mati sebagai berhentinya semua fungsi serebral, fungsi spontan sistem pernapasan, dan fungsi spontan sistem sirkulasi tanpa bisa pulih kembali. ${ }^{1}$

Kematian adalah suatu proses yang dapat dikenali secara klinis pada seseorang melalui tanda kematian yaitu perubahan yang terjadi pada tubuh mayat. Hal ini merupakan hal yang sangat penting dalam investigasi suatu kasus kematian, dimana perubahan postmortem banyak memberikan informasi baik mengenai waktu kematian, penyebab, maupun mekanisme kematian.,

Autolisis postmortem adalah kematian sel mirip nekrosis yang berlangsung bersamaan dengan kematian. Autolisis adalah perlunakan dan pencairan jaringan yang terjadi dalam keadaan steril melalui proses kimia yang disebabkan oleh enzimenzim intrasel. Autolisis biasanya berkaitan dengan otopsi dan pengakuan dari suatu fenomena, dan sangat penting untuk menjelaskan suatu kasus forensik. Perubahan autolisis dapat membantu dalam menentukan waktu kematian, terutama dalam beberapa jam pertama. Autolisis postmortem tergantung pada berbagai faktor, faktor yang paling penting adalah periode postmortem. ${ }^{4-6}$

Penelitian mengenai perubahan makroskopik dan mikroskopik postmortem dari organ-organ termasuk ureter sebagai alternatif perkiraan waktu kematian belum banyak dilakukan dan masih kurang yang membahasnya. Umumnya penelitian tersebut menggunakan hewan coba tikus. Penelitian ini menggunakan babi sebagai hewan coba karena secara anatomi dan fisiologi (fungsi) mirip dengan manusia, walaupun sistemnya berbeda. Babi adalah pemakan segala (omnivora) seperti manusia dengan ukuran dan fungsi jantung, ginjal dan pankreas babi mirip manusia.

\section{METODE PENELITIAN}

Jenis penelitian ini ialah deskriptif yang dilakukan di laboratorium AnatomiHistologi Fakultas Kedokteran Universitas Sam Ratulangi Manado, serta Pusat Diagnostik Patologi Anatomi Manado pada bulan November 2016. Hewan coba yang digunakan ialah dua ekor babi dengan berat $\pm 20 \mathrm{~kg}$ yang secara fisik aktif, sehat, dan tanpa luka.

\section{PROSEDUR PENELITIAN}

Hewan coba pertama dan kedua dimatikan. Setelah hewan coba berhenti bernapas, dicatat waktu kematian. Dilakukan irisan longitudinal pada abdomen sekitar $15 \mathrm{~cm}$. Isi abdomen yang menutupi ureter dikeluarkan sampai terlihat bagian ureter. Dilakukan pengambilan dokumentasi (makroskopik) dan pengambilan sampel (mikroskopik) untuk waktu 1 jam, 2 jam, 3 jam, 4 jam, 5 jam, 6 jam, 9 jam, 12 jam, 15 jam, 18 jam, 21 jam, 24 jam, 30 jam, 36 jam, 42 jam, 48 jam. Untuk mikroskopik diambil potongan ureter dengan potongan transversal lalu semua sampel difiksasi dengan formalin $10 \%$ dan disiapkan untuk pembuatan sediaan histologik. Sediaan histologik diidentifikasi dengan mikroskop cahaya Olympus CX 21 dan Optilab viewer.

\section{HASIL PENELITIAN}

Pada gambaran makroskopik 1 jam (Gambar 1), 2 jam, 3 jam, dan 4 jam postmortem didapatkan ureter berwarna merah, konsistensi kenyal dan panjang ureter $14 \mathrm{~cm}$. Setelah 5 jam postmortem warna ureter berubah menjadi merah kecoklatan, konsistensi berubah menjadi lunak, dan panjangnya menjadi $13 \mathrm{~cm}$ (Gambar 2). Mulai 12 jam postmortem terjadi perubahan konsistensi yaitu terdapat sebagian yang lunak sedangkan bagian lainnya mengeras. Pada 15 jam postmortem konsistensi ureter berubah menjadi keras dan pada 30 jam postmortem, terjadi perubahan warna ureter menjadi coklat kehitaman (Gambar 3) yang diamati sampai 48 jam postmortem (Gambar 4). 


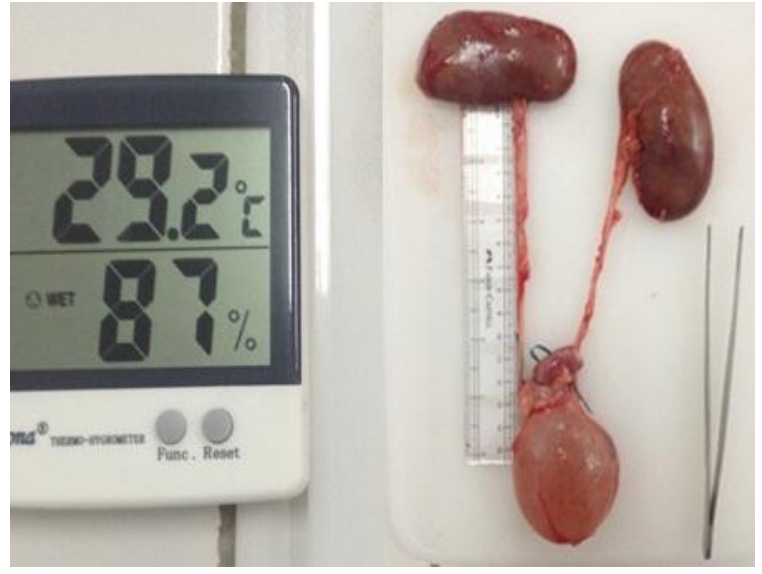

Gambar 1. Makroskopik ureter 1 jam postmortem

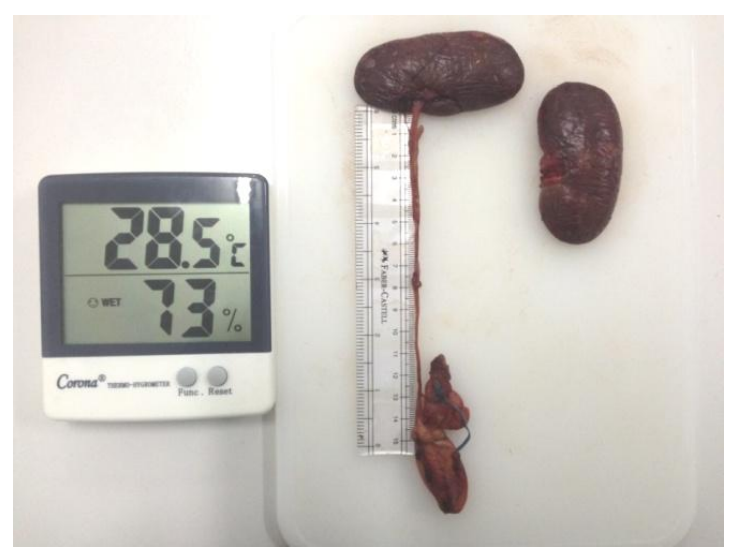

Gambar 3. Makroskopik ureter 30 jam postmortem

Pada gambaran mikroskopik 1 jam dan 2 jam postmortem lapisan mukosa (epitel transisional dan lamina propria) sulit diidentifikasi; hal ini mungkin diakibatkan oleh kontraksi sel-sel otot lapisan muskularis postmortem yang menyebabkan terlepasnya epitel transisional dari lamina propia (Gambar 5).

Pada 3 jam postmortem, epitel transisional sudah dapat diidentifikasi. Batas dan inti sel terlihat jelas. Lamina propia dan lapisan muskularis dapat diidentifikasi dengan jelas (Gambar 6).

Pada 4 jam postmortem lamina propia dan lapisan muskularis telah mengalami kongesti, batas dan inti sel epitel transisional masih dapat diidentifikasi dan terlihat jelas (Gambar 7).

Pada 5 jam postmortem ditemukan adanya kongesti pada lamina propia dan

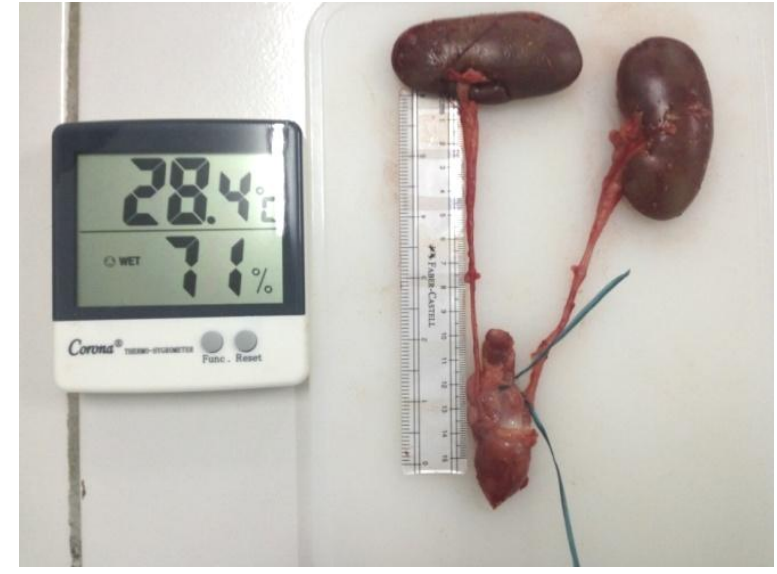

Gambar 2. Makroskopik ureter 5 jam postmortem

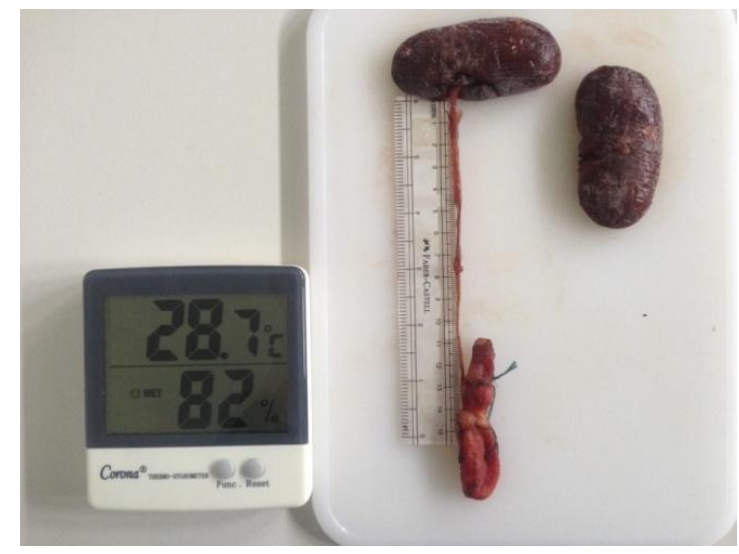

Gambar 4. Makroskopik ureter 48 jam postmortem

lapisan muskularis, sebagian inti sel epitel transisional piknotik dan batas sel epitel tidak jelas (Gambar 8) yang makin bertambah dengan berjalannya waktu.

Pada 15 jam postmortem sebagian besar lapisan epitel transisional terlepas dari lamina propia dan sel-sel inti piknotik makin jelas. Lamina propia dan lapisan muskularis tetap mengalami kongesti (Gambar 9). Perubahan mikroskopik tetap berlangsung pada pengamatan 24 jam postmortem.

Pada 30 jam postmortem tampak lapisan epitel transisional telah terlepas, lamina propria dan lapisan muskularis mengalami kongesti. Secara keseluruhan, struktur lapisan ureter telah sulit diidentifikasi (Gambar 10).

Pada 48 jam postmortem struktur lapisan ureter telah sulit diidentifikasi. 


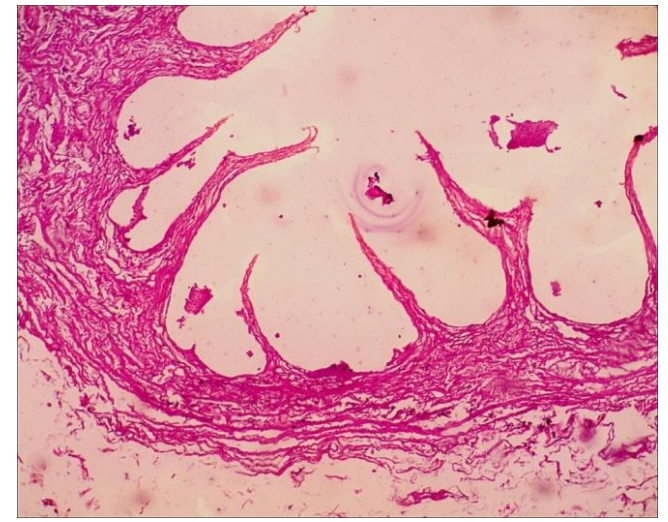

Gambar 5. Mikroskopik ureter 1 jam postmortem (100x). Lapisan mukosa sulit diidentifikasi

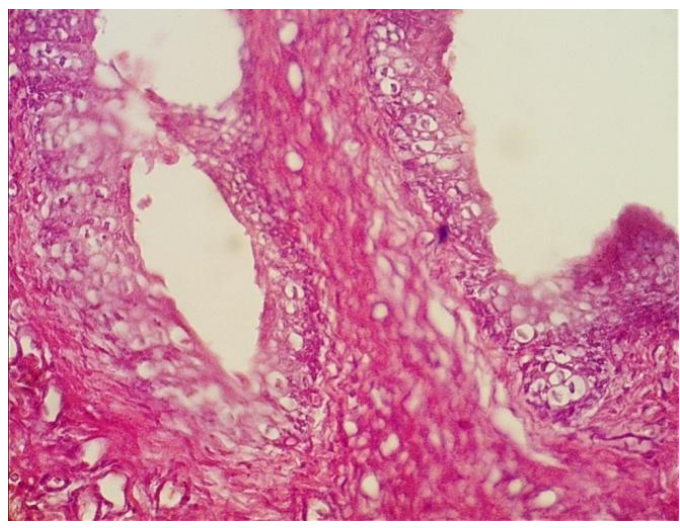

Gambar 7. Mikroskopik ureter 4 jam postmortem (400x). Tampak kongesti lamina propria dan lapisan muskularis

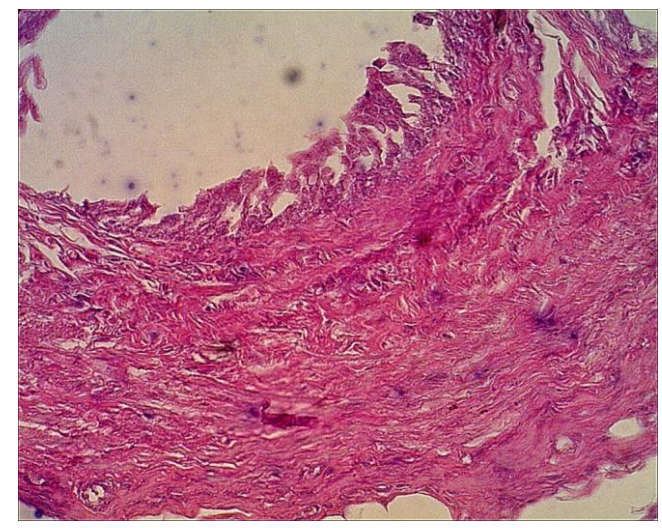

Gambar 9. Mikroskopik ureter 15 jam postmortem (400x). Tampak sebagian lapisan epitel transisional telah terlepas dari lamina propia dan sel-sel dengan inti piknotik makin jelas. Lamina propia dan lapisan muskularis tetap mengalami kongesti

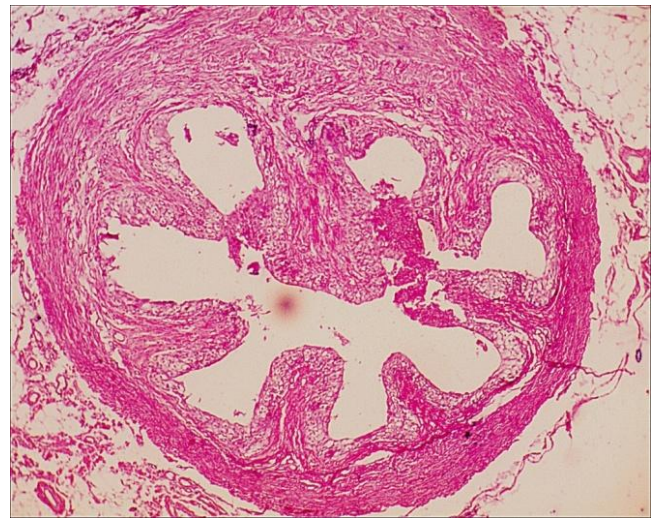

Gambar 6. Mikroskopik ureter 3 jam postmortem (100x). Lapisan-lapisan ureter dapt diidentifikasi

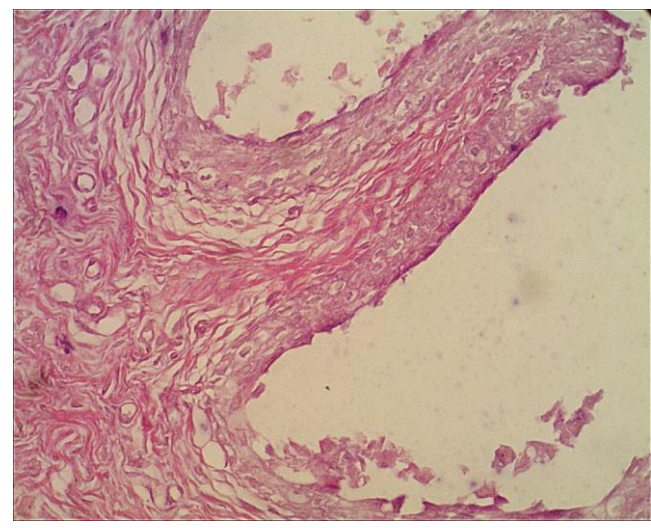

Gambar 8. Mikroskopik ureter 5 jam postmortem (400x). Sebagian inti sel epitel transisional tampak piknotik

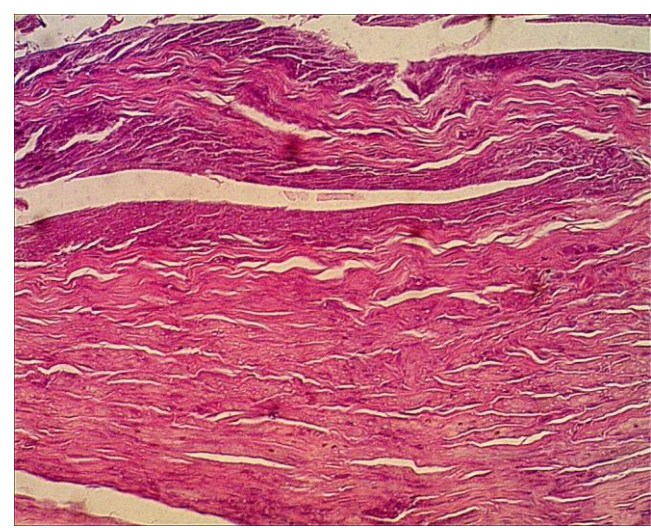

Gambar 10. Mikroskopik ureter 30 jam postmortem (400x). Tampak lapisan epitel transisional telah terlepas, lamina propria dan lapisan muskularis mengalami kongesti. Secara keseluruhan, struktur lapisan ureter telah sulit diidentifikasi 


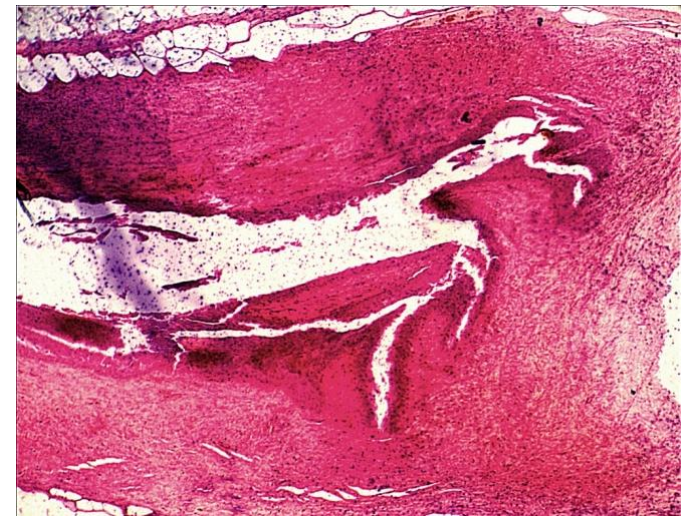

Gambar 11. Mikroskopik ureter 48 jam postmortem (100x). Struktur lapisan ureter telah sulit diidentifikasi.

\section{BAHASAN}

Memperkirakan saat kematian yang mendekati ketepatan sangat penting dalam penyidikan. Faktor-faktor yang memengaruhi perubahan pada mayat yaitu terjadinya penurunan suhu, terbentuknya lebam mayat, terbentuknya kaku mayat, terjadinya pembusukan, adipocere dan mumifikasi serta terjadinya perubahanperubahan biokimiawi. Mahkluk hidup yang telah mati akan mengalami perubahan sehingga memberikan gambaran secara kasat mata (perubahan secara makroskopik) dan juga tidak kasat mata (secara mikroskopik). ${ }^{7}$

Pada perubahan makroskopik postmortem, dapat ditemukan tanda-tanda pembusukan. Pembusukan adalah proses campuran dari proses internal dan external. Proses internal yang terjadi yaitu autolisis yang terjadi pada sel tubuh akibat enzim yang dibebaskan pasca mati, sedangkan proses externalnya dipengaruhi oleh bakteri, jamur, suhu dan kelembaban lingkungan. Autolisis adalah perlunakan dan pencairan jaringan yang terjadi dalam keadaan steril melalui proses kimia yang disebabkan oleh enzim-enzim intraseluler, sehingga organ-organ yang kaya dengan enzim-enzim akan mengalami proses autolisis lebih cepat daripada organ-organ yang tidak memiliki enzim. Proses pembusukan yang paling optimal terjadi pada suhu $70-100^{\circ} \mathrm{F}$ atau sekitar $21-38^{\circ} \mathrm{C}$. Pada suhu dibawah $50^{\circ} \mathrm{F}\left(10^{\circ} \mathrm{C}\right)$ atau diatas $100^{\circ} \mathrm{F}\left(38^{0} \mathrm{C}\right)$, proses pembusukan menjadi lebih lambat akibat terhambatnya pertumbuhan mikroorganisme. Pada proses pembusukan diperlukan juga kelembaban udara dan kelembaban udara tinggi akan mempercepat proses pembusukan, sedangkan proses pembusukan dapat terhambat jika kelembaban udara disekitarnya rendah. $^{8}$

Penelitian ini bertujuan untuk mengamati perubahan makroskopik postmortem dan menilai perubahan warna, konsistensi, dan panjang dari ureter hewan coba postmortem. Suhu ruangan rata-rata selama 48 jam postmortem ialah $28,4^{0} \mathrm{C}$ dan kelembaban rata-rata $77 \%$. Berdasarkan hasil penelitian, pada 1 jam postmortem terlihat ureter berwarna merah, konsistensi kenyal dan panjang ureter 14 $\mathrm{cm}$. Tidak ditemukan perubahan sampai 4 jam postmortem. Pada 5 jam postmortem warna ureter berubah menjadi merah kecokelatan dan panjang ureter menjadi 13 $\mathrm{cm}$ dengan konsistensi yang lunak. Pada 12 jam postmortem konsistensinya berubah menjadi keras. Sampai pada 24 jam postmortem tidak ditemukan perubahan baik warna, konsistensi maupun panjang. Pada 30 jam postmortem tampak adanya perubahan warna dari merah kecoklatan menjadi coklat kehitaman dan tidak ditemukan perubahan untuk konsistensi dan panjangnya.

Pada postmortem aliran darah yang memasok oksigen ke seluruh tubuh terhenti sehingga akan tampak perubahan secara mikroskopik yaitu sel-sel yang mengalami nekrosis yang kemudian berlanjut pada kematian sel. Penelitian ini juga bertujuan untuk mengamati perubahan mikroskopik ureter pada hewan coba postmortem. Pada penelitian perubahan mikroskopik ureter ini, yang diamati adalah epitel transisional (mukosa), lamina propia dan lapisan sel otot. Berdasarkan hasil penelitian, pada 1 jam dan 2 jam postmortem, mungkin lapisan sel otot mengalami kontraksi yang menyebabkan terlepasnya (deskuamasi) epitel transisional dari lamina propia sehingga sulit untuk diidentifikasi. Pada 3 jam postmortem, epitel transisional sudah dapat diidentifikasi. Batas dan inti sel 
terlihat jelas. Lamina propia dan lapisan sel otot dapat diidentifikasi dan terlihat jelas. Studi mengenai perubahan mikroskopik postmortem dari berbagai organ umumnya menggunakan hewan coba tikus. Zdravkovic et al. ${ }^{9}$ meneliti organ ginjal tikus pada 1 jam postmortem dan melaporkan perubahan struktur epitel tubulus dari jaringan ginjal tampak nyata setelah 4 jam postmortem. $^{9}$ Penelitian organ ginjal pada hewan coba babi yang dilakukan oleh Rahmadana et al. ${ }^{10}$ melaporkan bahwa perubahan struktur selsel tubuli proksimal mulai tampak setelah 30 menit post-mortem. ${ }^{10}$ Penelitian mengenai perubahan histologik pada pembuluh darah ginjal dan ureter yang dilakukan oleh Kanwar et al. ${ }^{4}$ pada 4 jam 30 menit sampai 13 jam postmortem menggunakan kadaver manusia dan menyatakan bahwa pada ureter sudah terjadi retraksi epitel dan terganggu di beberapa tempat, kerusakan jaringan fibrosa pada 4 jam 30 menit dengan suhu lingkungan $23.9 / 33.4^{\circ} \mathrm{C}$ dan kelembaban $75 / 95 \%$. Pada penelitian ini lamina propia dan lapisan sel otot sudah mengalami penimbunan cairan (kongesti) pada 4 jam postmortem. Batas dan inti sel epitel transisional dapat diidentifikasi dan terlihat jelas. Kanwar et al. ${ }^{4}$ juga menyatakan bahwa pada 5 jam postmortem struktur sel sudah terganggu, terjadi retraksi dan disrupsi, serta ruang kosong. Pada penelitian ini, ditemukan adanya kongesti lapisan sel otot, inti sel epitel transisional piknotik serta batas sel tidak jelas pada 5 jam postmortem. Pada 15 jam postmortem, epitel transisional mengalami deskuamasi dari lamina propia dengan inti piknotik sehingga sulit untuk diidentifikasi. Lapisan sel otot mengalami kongesti.

Pada gambaran histologik ureter menggunakan kadaver 13 jam postmortem, didapatkan struktur ureter yang terganggu, terjadi retraksi dan disrupsi pada sel epitel, serta piknotik terlihat jelas. ${ }^{4}$ Pada penelitian ini, setelah 36 jam postmortem ditemukan adanya kongesti dan pengerutan dari lapisan sel otot, inti sel epitel transisional menyusut dan berwarna gelap serta batas tidak jelas (piknotik).

Tomita $\mathrm{Y}$ et $\mathrm{al}^{11}$ melakukan penelitian deskriptif terhadap perubahan struktural postmortem ginjal, pankreas, hati, jantung dan otot skelet pada tikus wistar, dan menyatakan bahwa perubahan tersebut terjadi tidak serentak, yaitu: pertama kali pada ginjal dan paling lambat pada otot skelet. Penelitian yang dilakukan oleh Pualillin et al. ${ }^{12}$ menyimpulkan bahwa perubahan gambaran histologik hepar babi mulai tampak pada menit ke 30 postmortem ditandai kongesti jaringan parenkim hepar disertai dilatasi sinusoid. Lilingan et al. ${ }^{13}$ yang melakukan penelitian menggunakan gaster babi menyatakan bahwa terjadi perubahan struktur pada kelenjar fundus pada 2 jam postmortem dan kerusakan sel kelenjar pada 7 jam postmortem.

Perlu dilakukan penelitian lanjut yang lebih detail mengingat terdapatnya perbedaan struktur histologik dan fisiologi antara organ-organ manusia dan hewan coba yang dapat memengaruhi proses dekomposisi. Hasil penelitian ini diharapkan dapat menjadi penelitian awal agar dapat mengaplikasikan hewan coba dalam menentukan saat kematian sebagai pembanding, terutama pada kasus kematian tidak wajar dengan organ atau anggota tubuh yang rusak sebagian sehingga tandatanda kematian sulit dievaluasi secara forensik.

\section{SIMPULAN}

Berdasarkan hasil penelitian, dapat disimpulkan bahwa perubahan makroskopik ureter pada hewan coba postmortem, mulai tampak pada 5 jam postmortem ditandai dengan perubahan warna, konsistensi dan panjang ureter yang berlangsung terus sampai 48 jam postmortem.

Perubahan mikroskopik ureter hewan coba postmortem mulai tampak pada 4 jam postmortem yang ditandai dengan adanya kongesti, batas dan inti sel epitel transisional dapat diidentifikasi dan terlihat jelas. Pada 5 jam postmortem sebagian inti 
sel transisional tampak piknotik. Pada 15 jam postmortem tampak sebagian lapisan epitel transisional telah terlepas dari lamina propia dan sel-sel dengan inti piknotik makin jelas. Secara keseluruhan, pada 30 jam postmortem struktur lapisan ureter telah sulit diidentifikasi.

Diharapkan perubahan makroskopik dan mikroskopik uteter ini dapat diaplikasikan untuk perkiraan saat kematian.

\section{SARAN}

Disarankan untuk penelitian lanjut menggunakan organ-organ lain dengan interval waktu yang lebih rinci.

\section{DAFTAR PUSTAKA}

1. Idries AM, Tjiptomartono AL. PenerapanIlmu Kedokteran Forensik dalamProses Penyelidikan. Jakarta: Sagung Seto, 2008; p. 39.

2. Howard C, Adelman M. Establishing the time of death. In: ForensicMedicine. New York: Infobase Publishing, 2007; p. 20-6.

3. Morgan C, Nokes LD, Williams JH, Knight BH. Estimation of the post mortem by multiple-site temperature measurements and the use of a new algorithm. Forensic Sci Int. 1988;39(1):89-95.

4. Kanwar Y, Goyal M, Roul B. Postmortem histological sequential change in human renal vessels and pelvis of ureter up to thirteen hours post mortem interval. International Journal of Advanced Research. 2015;3:1167-81.

5. Dahlan S. Ilmu Kedokteran Forensik Pedoman bagi Dokter dan Penegak
Hukum. Semarang: Badan Penerbit Universitas Diponegoro, 2000.

6. Pratama AA, Suharto G, Relawati R. Hubungan antara lama waktu kematian dengan kerusakan histopatologik otot jantung tikus Wistar internet]. 2010 [cited 2016 Sept 9]. Available from: http://eprints.undip.ac.id/23135/1/Arie_ Aldila.pdf

7. Degenerasi dan nekrosis. 2013 [cited 2016 Desember 6]. Available from: http://www.slideshare.net/KampusSaki nah/degenerasi-dan-nekrosis

8. Firsthya O. Pembusukan [internet]. 2014. [cited 2016 Sept 17]. Available from: http://eprints.undip.ac.id/44862/3/Onne Firsthya_22010110130178_BAB2KTI. pdf

9. Zdravkovi M, Kostov M, Stojanovi M. Identification of postmortem autolytic changes on the kidney tissue using pas stained method. 2006. Available from: http://facta.

junis.ni.ac.rs/mab/mab200603/mab200 603-12n.pdf

10. Rahmadana B. Gambaran histologik ginjal hewan coba postmortem. eBm. 2014;2(2):417.

11. Tomita $Y$, Nihira $M$, Ohno $Y$, Sato $S$. Ultrastructural changes during in situ early postmortem autolysis in kidney, pancreas, liver, heart and skeletal muscle of rats. Legal Medicine. 2004; 6:25-31.

12.Pualillin NK. Gambaran histologik hepar postmortem pada hewan coba. JBM. 2014;6(2):99.

13. Lilingan M. Gambaran histologik gaster pada hewan coba selama 24 jam postmortem. eBm. 2016;4(1). 